\title{
Q.
QNEEN'S
UNIVERSITY
BELFAST
}

\section{Religion, respect and public reason}

McBride, C. (2017). Religion, respect and public reason. Ethnicities, 17(2), 205-219.

https://doi.org/10.1177/1468796817690781

\section{Published in: \\ Ethnicities}

\section{Document Version:}

Peer reviewed version

\section{Queen's University Belfast - Research Portal:}

Link to publication record in Queen's University Belfast Research Portal

\section{Publisher rights}

(C) 2017 the author.

This work is made available online in accordance with the publisher's policies. Please refer to any applicable terms of use of the publisher.

\section{General rights}

Copyright for the publications made accessible via the Queen's University Belfast Research Portal is retained by the author(s) and / or other copyright owners and it is a condition of accessing these publications that users recognise and abide by the legal requirements associated with these rights.

\section{Take down policy}

The Research Portal is Queen's institutional repository that provides access to Queen's research output. Every effort has been made to ensure that content in the Research Portal does not infringe any person's rights, or applicable UK laws. If you discover content in the Research Portal that you believe breaches copyright or violates any law, please contact openaccess@qub.ac.uk. 
Religion, Recognition, and Public Reason

Cillian McBride

School of History, Anthropology, Philosophy, and Politics

Queen's University Belfast

c.mcbride@qub.ac.uk

(Accepted for publication in Ethnicities 23.11.2016)

Keywords: religion, public reason, recognition, civility, integrity, democracy

Abstract:

Do the constraints of public reason unfairly exclude religious citizens? Two ways of framing the charge of exclusivity are examined: the burden of translation objection and the integrity objection. The first, it is argued, rests on a misapplication of the 'distributive paradigm' and fails to provide a convincing account of religious citizens' relationship to their beliefs. The 'integrity' objection, it is argued, relies on a theologically questionable account of 'wholeness' and drastically overestimates the threat to personal integrity posed by the duty of civility. It is argued here that it is a mistake to interpret the ideal of public reason as inimical to recognising religious citizens as co-deliberators and that, on the contrary, only a public reason centred account of democratic citizenship can ensure that religious citizens will be appropriately recognised. A rival, convergence, account of public reason, which seeks to relax the constraint of public reason and eliminate the duty of civility is rejected on the grounds that it fails to underwrite the appropriate recognition of citizens.

Critics allege that public reason is an exclusionary ideal that fails to recognise the equal status of religious citizens (Wolterstorff, 1997b, Quinn, 1997). I will argue that this is a misreading, and that a public reason-centred account of democratic citizenship is essential to recognising religious citizens as co-deliberators. The recognition sought here is not that typically associated with the so-called 
'politics of recognition' i.e. recognition of 'difference' or of the value of one's cultural contribution (Taylor, 1994). Instead, it is recognition of one's status as an equal. Darwall (1977: 38) captures this in terms of a contrast between 'recognition respect' and 'appraisal respect'. Appraisal respect, or social esteem, is due if one's actions are judged praiseworthy. Recognition respect, by contrast, is not earned, but is the respect to which one is entitled simply in virtue of being a person (Darwall, 1977). When religious citizens complain of the exclusionary effects of public reason they are not primarily complaining that their contribution to the wider culture has not been fairly appraised but rather that they are not recognised as having the equal status of co-deliberators (Eberle, 2002: 85).

Respect recognition is often treated as overly abstract and is narrowly identified with the possession of legal rights (Galeotti, 2002: 96), overlooking its role in shaping everyday social relations. This view overlooks the subtle inequalities in social authority involved in appraisal respect: who enjoys the authority to act as the appraiser dispensing, or withholding, the desired recognition (McBride, 2013)? Respect recognition, by contrast, presupposes not only mutual, but also equal authority to seek and grant recognition. It also fails to appreciate our deep emotional attachment to the expectation that we will be treated with respect by others and our interest in standing in this relationship to others - an attachment revealed by the emotional reactions of anger and resentment when our expectations are violated (Strawson, 1974, Honneth, 1992).

To enjoy recognition respect is to have others respond appropriately to one's personhood (Darwall, 1977: 38). Darwall (2006) understands this in terms of authority relations: we are recognised as having the equal authority to make claims on others and to respond appropriately to the claims they make upon us. To respond appropriately to someone as a person, then, is to see them as someone to whom you owe justifications for how you interact with them, and as someone empowered to 
demand justifications from you in turn. To enjoy equal respect, one must stand in a certain sort of relationship to others (Scanlon, 1998: 268), one of equal moral authority, evidenced in our commitment to practices of mutual justification. While typically deformed by status hierarchies of various sorts, whether ethnic, racial, religious, or organisational, the ideal of respect for persons, and the expectations it entails are embedded in the social relations of modern societies. The model of citizenship associated with public reason is an extension of this notion of respect for persons to the political sphere, in which citizens are to be respected as co-deliberators committed to mutual justification in the production of binding laws. Critics, however, claim that religious citizens' status as co-deliberators is threatened by the demand that they refrain from relying solely on religious reasons when deliberating about how to vote (Eberle, 2002: 109). I will argue that efforts to weaken the duty of civility in order to be more 'inclusive' fail to deliver on their promise of equal recognition.

\section{Public reason}

In deliberative conceptions of democracy voting is regarded as public rather than private (Elster, 1997). Rawls claims that citizens 'should be ready to explain the basis of their actions to one another in terms each could reasonably expect that others might endorse as consistent with their freedom and equality.' (Rawls, 1996: 218) This 'duty of civility', he argues, requires us to confine ourselves to public reasons in deliberating about how to use our 'common coercive force' (Rawls, 1996: 217). Religious reasons, are 'non-public' in the sense that, while they may be endorsed as reasons by those within churches, we cannot reasonably them to be endorsed by non-members. To vote on the basis of religious reasons alone, on this view, would be tantamount to denying the equal status of non-believers as co-deliberators, as it affirms that they may be coerced on the basis of reasons we could not reasonably expect them to endorse. Bypassing public justification in this way, no matter how altruistic the motivation, is attempting to dominate simply by weight of numbers and fails to recognise one's fellow citizens as equals to whom one owes an appropriate justification. 
Why should religious citizens accept this constraint? Coercive legislation that rests purely on reasons drawn from any particular faith can reasonably be rejected by those who do not adhere to that particular faith, whether they are themselves religious or not. The disqualification of religious reasons as sole grounds for legitimate coercion has its roots in recognition of the importance of individual conscience, religious or otherwise. Given that religious citizens themselves have historically bridled under the yoke of sectarian legislation, we can plausibly suppose that they have reason to endorse the idea of public reason. Justification here is not merely a matter of having valid reasons, sufficient to direct my own actions (Rawls, 1997: 786) but must be 'directed toward others' in terms we can reasonably expect them to endorse, and not merely in terms that are intelligible or 'accessible' to them (Vallier, 2011).

Rawls (1996: 214) suggests that the duty of civility might be thought of as applying only to '"constitutional essentials" and questions of basic justice', but he also argues that the idea of public reason may be extended to other cases if it can be shown to be plausible with respect to these two cases (Rawls, 1996: 215). Much more significant is the contrast he suggests between the 'inclusive' and 'exclusive' views of public reason. On the exclusive view comprehensive (including, but not restricted to) religious reasons are 'never to be introduced into public reason', while on the inclusive view it may be appropriate for citizens to introduce the full set of reasons they have for their political position, if by doing so, this strengthens the norm of public reason (Rawls, 1996: 247).

Rawls (1996: 248) suggests that the exclusive view may be appropriate in a 'well ordered' society, while the inclusive view may be more suitable to a society that is not yet well ordered. Subsequently, however, he refers simply to the 'wide' view of public reason (Rawls, 1997: 783-4). The earlier, 'inclusive', view allows religious reasons to be introduced into political debate only to 
explain how the public reasons advanced by religious advocates are supported from within their religious doctrines (Rawls, 1996: 249). On the 'wide' view, however, religious reasons may be introduced directly in support of legislation, subject to the proviso that appropriately public reasons must be offered in due course (Rawls, 1997: 784). It is not entirely clear what sort of time period is envisaged (Larmore, 2003), but in presenting the 'wide' view Rawls is at pains to stress that he envisages a positive role for the articulation of religious reasons within public deliberation, consistent with insisting that religious reasons alone cannot supply a legitimate basis for the exercise of legislative power. This account of the constraints of public reason clearly does not amount to a blanket exclusion of religion from the 'public sphere', and even allows that the articulation of religious reasons in the context of legislative debates may have positive value, in terms of enhancing mutual understanding and trust amongst citizens.

While the idea of public reason entails a very limited 'privatisation' of religious reasoning, religion is a private matter only with respect to one's deliberations about how to vote (subject to the qualifications noted above) and not with respect to discussions taking place in the background culture of the public sphere (Rawls, 1997). This 'privatisation', furthermore, might be regarded as an inescapable product of the fact of ethical and religious diversity typical of modern societies (Taylor, 2007), an underlying fact which the idea of public reason simply takes into account. How we are to reason about voting is a distinct issue, not to be confused with what we say 'in public' - a distinction which is at risk of being obscured by vagueness of the phrase, 'the public square' (Wolterstorff, 1997b, Wolterstorff, 1997a, Vallier, 2011). Public reason, as conceived here, does not count against the articulation of religious values and visions in public. 
On the view of public reasoning endorsed here, then, it is entirely proper for religious citizens to appeal to religious beliefs in conversation not only with co-religionists, who share the relevant theological tradition, but also in debate with others of different faiths and no faith in discussing the values at issue in matters of social and political controversy, e.g. the current refugee crisis, or more widely, in debates about the ethical direction of a given society or the modern world more generally. I take it that in these debates, religious citizens are not confined to explaining the bases of their positions, but may also seek to convince others of the value of these positions. The Pope's suggestion that Donald Trump's proposal for building a wall between the US and Mexico was 'unChristian', for example, would not be excluded by the account of public reason presented here, nor would other ethical interventions, such as religious condemnations of the materialism of contemporary Western society, for example. The duty of civility applies only to citizens in their role as legislators, not in their wider role as members of society. To seek to constrain these conversations would be to pursue a much more radical (and fundamentally illiberal) form of privatisation than that entailed by the idea of public reason.

\section{Public reason as an unfair burden}

One way to frame the complaint of exclusivity is to think of it in distributive terms as imposing an unfair burned on religious citizens (Ferrara, 2009) This approach is inspired by Habermas' warning that 'The liberal state must not transform the requisite institutional separation of religion and politics into an undue mental and psychological burden for those of its citizens who follow a faith.' (Habermas, 2006: 9) Ferrara (2009: 81) suggests that accepting the constraint of public reason, to the extent that it entails translation between religious and secular vocabularies, imposes an 'additional burden' on the religious and wonders if 'compensation' might be appropriate, given the 'intrinsically disadvantaged predicament of the religious conscience.' (2009: 86) Here the thought is that while religious citizens can 'translate' their religion-based claims into claims backed by public 
reasons, the work of translation is one which their secular fellow citizens do not have to undertake. Their situation, it seems, is analogous to that of minority linguistic groups compelled to interact with the institutions and public culture of a dominant linguistic group.

Religious citizens, on this view, are disadvantaged by the distribution of beliefs in their society, something over which they have no control, just as we might think that linguistic minorities are disadvantaged by the demographics of the state they reside in: the disadvantage that arises because of the way that social and cultural change has 'outstripped' their ethical and political outlooks. Where once a majority of citizens shared their outlook, now they find themselves in a minority on account of changes in the background culture over which they have, presumably, no control. This constitutes a disadvantage as it has become more difficult to secure agreement for certain projects which are supported by the particular religious reasons of the religious group in question, and within democratic political institutions this difficulty becomes one of an imbalance of political power to the extent that it may be more difficult to build majorities in favour of the projects in question. There seems no reason to doubt that this is a genuine disadvantage, although it is one which faces anyone who holds political views which are no longer, or not yet, popular. Secular egalitarians may be at least as disadvantaged in this respect as religious citizens, so it difficult to see this as a burden borne exclusively by religious citizens. What is not clear, however, is whether this sort of disadvantage amounts to an injustice: it is not obviously unfair that others disagree with you on important ethical and religious matters.

Firstly, the analogy with multicultural-style arguments which hinge on the background advantage enjoyed by members of majority cultures/linguistic groups, turns out to have one key limitation. In multicultural cases, the power of the contrast between minority and majority groups relies on 
further assumptions about the relative positions of the groups concerned, typically a history of colonialism in the case of the relations between settler societies and their indigenous peoples. In the case of many religious citizens, however, the historical background is rather different: for Christians in Europe and North America at least, they have a history rather of social and political dominance (Laborde, 2008), and in this context some complaints about the loss of authority enjoyed by religious arguments appear to be motivated simply by the loss of privileged social status. While this will not be true of minority religions, it is notable that members of Christian churches have frequently been vociferous in their complaints about their loss of authority in the context of secularization.

Secondly, the idea of 'translation' appears to be misleading in this context. It encourages the idea that religious patterns of thought are as incomprehensible to the secular citizen as a foreign language is to someone who does not speak it. In reality this misrepresents the historical development of liberal and democratic ideas, which have grown out of a variety of ethical and religious traditions with the result that our public culture exhibits many points of overlap and affinity between religious and 'secular' political ideas (Audi, 1997: 13). One the one hand, we can find the origins of modern egalitarianism emerging out of the reinterpretation of religious ideas such as the idea that we are all equally God's 'workmanship' (Waldron, 2002), while, on the other hand, we can find theological opposition to modern ideas about dignity and democratic equality giving way to an appropriation of these ideas into religious teaching - as happened in the case of the Catholic church's position on democracy and human rights in the post-war era (Rosen, 2012).

Thirdly, this line of argument clearly owes something to luck egalitarian intuitions about the way in which the operation of brute luck, rather than free choice, may give rise to complaints of injustice (Dworkin, 1981). As the epistemic asymmetry involved here stems from changes in the background 
culture over religious citizens themselves had no control, this asymmetry is a product of brute luck and hence the question of compensation arises. Even on luck egalitarian grounds, however, we might have reason to wonder if we can treat the distribution of belief as simply a matter of brute luck. It is true, of course, that beliefs are not chosen but are typically acquired through socialization into particular communities and their practices and traditions. That said, forcing religious faith into the mould of a so-called 'ascribed' identity also seems to get something wrong about how religious citizens understand themselves.

While many religious narratives, like that of the Pauline conversion, emphasize that faith is a gift, and, as such lies outside our control, it is also true that the religious life typically demands commitment on the part of the believer, who is called upon to open her heart to God, to listen to his commands, to resist temptations and to bear witness to her faith in her daily life, and so on. Religious faith is not simply a matter of socialization, but also of having commitments that must be manifested one way or another in one's life. Religious texts constantly warn the faithful to be on their guard against sin and to resist becoming entangled in the ways of the world: faith requires work. As such, it seems odd to treat religious faith simply as a matter of brute luck. While this may fit the experiences of those who only have a merely nominal religious affiliation, it is not the appropriate way to understand the lives of the faithful, as it is not how they understand themselves and their relationship to their beliefs.

Even if we grant the point that faith itself is not chosen, the luck-egalitarian inspired approach to this problem looks like a misapplication of the 'distributive paradigm' in this case (Young, 1990, Honneth, 2004). To think of beliefs on the model of resources is to make a mistake about the role they play in their lives. We would not aim for a redistribution of beliefs, for example, in order to eliminate the 
disadvantages attendant on being in dissenting minority, nor could we imagine religious believers accepting compensation for their disadvantaged position when their faith is the very thing that animates their lives and endows them with meaning. To compensate in such circumstances would simply be to insult the intended recipients of compensation (Wolff, 1998). As Anderson argues, the luck egalitarian impulse fails to capture the core of egalitarianism: the ideal of a society of free and equal persons, whose social relationships reflect mutual respect for that status (Anderson, 1999). Religious citizens may have reason to suppose that their secular fellows do not appreciate the strength of their commitments and obligations, but the suggestion that their faith is a form of disability for which they might be compensated in fact reflects this lack of understanding rather than remedying it.

\section{The integrity objection}

The burden of translation view arises in a context in which once dominant religious ideas, and the churches that espouse them, appear to have lost their social prestige due to changing social and political conditions. The integrity objection to public reason is independent of such considerations. Here the idea is that religious citizens have the conviction that they 'ought to strive for wholeness, integrity, integration in their lives: that they ought to allow the Word of God, the teachings of the Torah, the command and example of Jesus, or whatever to shape their existence as a whole, including their social and political existence.' (Wolterstorff, 1997a: 105) The integrity objection centres on the problem of coping with the tensions between one's role as a religious believer and the demands of one's role as a citizen. Public reason, in particular, is taken to threaten the integrity of religious citizens to the extent that in their civic role, they are not permitted to appeal solely to their full set of reasons, but must seek additional, public, reasons, while in their private lives, they are free to act on their religious reasons alone. Does the duty of civility necessarily threaten the 
integrity and self-respect of religious citizens, or is Wolterstorff overstating the demands of the duty of civility?

It is not obvious, however, that the religious citizens have good religious reasons to expect their lives to be whole in the way that Wolterstorff suggests. This is because that for many religions, believers are taught to expect a significant degree of alienation from the things of this world. On such views there is a sharp distinction between the sacred and the mundane and the eyes of the believer must be firmly fixed not on this world, but upon the next. Augustine (1984: 761) captures this basic division in terms of a tension between the 'City of God' and the 'City of Man', he observes that the believer lives in this world only as an 'alien sojourner'. For the person of faith, this world poses dangers and challenges as they make their way to their true home. Their faith tells them that they are being tested here and must resist being drawn into the ways of the world - it tells them to expect to be alienated from the secular world and, in fact, to insist upon this alienation which itself has a religious meaning (McConnell, 2000: 91). From the point of view of religious faith, then, it seems odd to complain about threats to integrity, when these are only to be expected, and possibly even welcomed as part of the trials of the faithful (Margalit, 1996). As such, any tension between secular and spiritual roles is a product of the spiritual condition itself, rather than an threat to that condition imposed from outside. The wholeness that is to be sought is only to be found in union with God: there are no political arrangements that can satisfy that desire. As Rowan Williams (2012: 61) observes, 'the Christian tradition rests upon a strong conviction that no political order other than the body of Christ can claim the authority of God.'

The integrity objection, then, seems to rely on a remarkably secular reading of the spiritual desire for wholeness, if it assumes that this can be satisfied by the right sort of political institutions. Turning 
from these theological complications, to purely sociological considerations, the desire for 'wholeness' looks like a demand for a much simpler social order in which there is no prospect of finding that one's various duties and obligations cannot come into conflict. It is hard to imagine such a society, one so lacking in complexity that one would be insulated against the possibility that one might find oneself pulled in different directions by one's duties. As the example of Antigone, tragically unable to fulfil the duties attached to her roles of daughter and of sister, shows, such conflicts can easily arise in a premodern society (Pinkard, 1994) so it is especially difficult to imagine how one might avoid the possibility of such tensions in a complex modern social order. Whenever we find ourselves occupying a variety of roles, within our families, associations, organisations, states, etc. there is the possibility that conflicts may arise between the respective demands that they make of us. To find ourselves 'divided' in this way is simply part and parcel of being situated within a social order, so to expect 'wholeness' in the sense that one might never be faced with conflicting duties and obligations, starts to look like one is simply wishing the world away. In a world in which citizenship is distinct from church membership, the possibility of tensions between these roles cannot be ruled out.

The fact that we typically occupy a variety of roles, each of which comes with their own normative strings attached, is not enough to undermine one's integrity - it merely makes it possible for challenges to it to arise. Even then, whether we maintain our integrity or lose it, depends on how we respond to these challenges: simply having potentially conflicting roles is not enough to threaten one's integrity. The situation is complicated by the fact that there are two recognisable ways in which one can lack integrity: either by failing to be true to one's authentic self, by prioritising conventional demands, or, in direct contrast, by failing to live up to the demands of some particular role, as a biased, or corrupt, judge might (McFall, 1987). Consider the recent case of the government official in Kentucky who refused to issue marriage licences to gay couples on the grounds that it 
conflicted with her religious beliefs (Holpuch, 2015). While we may recognise her situation as one in which she felt pulled in different directions, her choice to continue to occupy her official role but to refuse to act as the law required itself might be thought to display a lack of integrity in the second sense noted above (McFall, 1987). Had she resigned her position on the grounds that it required her to act contrary to her religious convictions, by contrast, we might judge that she had displayed integrity. Had she adopted this course of action, we might suppose that she had chosen to bear witness to her faith and accept the consequences of that commitment (Jones, 1994), while in acting as she did she sought to abuse her position of authority. Similarly, we might think that had she chosen to embark on a campaign of civil disobedience, publicly breaking the law to protest against what she takes to be a grave immorality, this too would have displayed integrity - even if we were out of sympathy with her views. On Wolterstorff's view, it seems, it is unfair even to expose religious believers to apparent dilemmas such as this - simply being faced with conflicting obligations threatens their integrity. It is more plausible, however, to suppose that one's integrity is revealed rather in how one chooses to respond to such situations. Furthermore, it is simply unrealistic to suppose that anyone, religious or otherwise, could ever be insulated from the possibility of facing such conflicts.

In any case, it is not clear that the pursuit of integrity must have overriding value: it is not hard to imagine sincere bigots, unwavering in their single-minded pursuit of repugnant goals. While they may be true to their particular vision, we should not accommodate them to the extent that they are allowed to dominate others. Wolterstorff's appeal to integrity is not tempered by any consideration of the content of the duties concerned, and consequently, it affords too much leeway to the theocratically inclined, who refuse to recognise any limit to their political ambition. The duty of civility is intended to guard against domination by sheer weight of numbers, alongside more formal constitutional safeguards. That some may find this a restraint on their religio-political projects is not 
itself an objection against it, for it also protects them against the projects of others. It is a moral, rather than a legal duty (Rawls, 1997: 769), in contrast to the duties attached to the clerk's position discussed above, so citizens cannot be forced to engage in public reasoning contrary to the dictates of their conscience. In extreme cases, religious citizens may even choose to withdraw from political engagement altogether (in states which do not make voting compulsory). It is not at all clear, however, that religious citizens must view the duty of civility as a significant burden, still less that to uphold this norms must somehow threaten their self-respect. The duty of civility does not demand that we endorse reasons contrary to those derived from our religious convictions, but only that we seek additional, supporting reasons that may be endorse by others who we cannot reasonably expect to endorse our purely religious reasons. While it may be the case that certain sorts of scriptural fundamentalists may be unable or unwilling to consider whether there are additional, public, reasons they could offer in support of their legislative projects, it seems highly unlikely that many religious citizens will regard this as a significant obstacle. Why should they suppose that the commands of a wise and loving God cannot be supported by reasons that may be endorsed by those who do not share their faith? At best, the integrity objection to public reason appears to grossly overestimate the burdens of public reasoning, while, at worst, it strikes at the fundamental distinction between the role of citizen and that of church member, licensing the pursuit of theocratic domination.

\section{Relaxing the constraints of public reason}

Rawls does not suppose that citizens who are guided by the duty of civility are likely to agree in their political judgements - here as elsewhere, the burdens of judgement apply. Public reasoning is not a method for producing political agreement and voting is necessary to produce a collective decision in the face of disagreement about what legislative proposal is best supported by public reasons (Rawls, 1996: 241). It might be thought that public reason is redundant if it cannot produce agreement and 
we must fall back on an aggregative procedure after all, but it is not to be thought of as a method for producing consensus: its significance lies in the way that it demands that citizens recognise each other as co-deliberators. Even if citizens come to different views about what public reason supports, they have discharged their duty to consider whether they could justify the measure in question to their fellows in terms they could not reasonably endorse. Some have suggested that the duty of civility should legally enforceable (Bonotti, 2014) but if we can expect significant disagreement as to what public reasons require, then it is hard to see how this could ever be legally enforceable. Citizens must rely on their judgement in determining whether or not they have discharged their duty of civility. Only by reasoning with each other can they form a sense of what they can reasonably expect others to endorse. The content of public reason is not given in advance, but emerges through this process of reasoning.

In addition, the attempt to reduce it to a legally enforceable formula fails to appreciate its role in the ethos of citizenship itself. The duty of civility expresses an underlying commitment to the ideal of self-governing community of free and equal citizens. This normative understanding of citizenship underlies and guides the design of the formal institutions of liberal democracy (Rawls, 1996: 218). To the extent that this understanding is widely shared, citizens will recognise that they owe each other justifications for any proposed use of political power, and recognise each other as having the status of being who must be reasoned with, rather than about (Gutmann and Thompson, 1996). Respecting others is not, obviously, a matter of accepting their arguments, or deferring to their beliefs, but of recognising their status as the sort of beings who can respond to reasons, and to whom reasons are therefore owed. We may manifest our respect for our fellow citizens while rejecting their arguments: what matters is that we engage deliberatively with these arguments. 
Eberle (2002: 84), while endorsing the idea that civic respect requires 'conscientious engagement' with other citizens, rejects the idea that citizens must refrain from voting solely on the basis of their religious reasons. His rejection of the restraint required by the duty of civility relies, however, on too close an identification of justification with the achievement of agreement. He presents an example in which a religious citizen, Elijah, having failed to convince his fellow citizens with public reasons in favour of his liberation theology inspired scheme for ameliorating poverty, then votes on the basis of religious reasons alone (Eberle, 2002: 113-4). Eberle argues plausibly that Elijah in 'pursuing justification' has respected his fellow citizens but concludes, less plausibly, that Elijah cannot therefore be condemned for voting on the basis of his religious reasons. However, Eberle attaches too much significance to Elijah's failure to secure agreement, and not enough to the fact that he successfully identified public reasons in favour of his anti-poverty programme. If Elijah has identified public reasons then the fact that others did not in fact accept them does not mean that his proposal is not publicly justified. Consequently, it seems odd to say that Elijah voted on the basis of his religious reasons alone. Elijah, it seems, has discharged his duty of civility, and has not failed to recognise his fellow citizens as co-deliberators in voting as he did.

Critics of Rawlsian public reason have argued that it imposes an unreasonably high bar for public reasoning: it insists that public reasons must be shared by the public, at least in principle (Gaus, 2009, Vallier, 2011). This 'consensus' model - the term is apt in that citizens are under an obligation to uncover reasons that they believe can reasonably be shared, even if they disagree ultimately about what these are - does not take the fact of reasonable pluralism seriously enough (Gaus, 2009: 25-6) and should be rejected in favour of a 'convergence' model of public reason instead. On this view, it is sufficient that citizens vote for reasons that can be shared with some others, even if not all, or many: 'it is justified because we all have our own, different reasons to endorse it' (Gaus, 2009: 26). On this view, we may regard laws as supported by public reason when they can be regarded as 
having support drawn from a plurality of sources. While this is reminiscent of Rawls' notion of an overlapping consensus, it is a distinct view. While Rawlsian deliberators may end up disagreeing about what public reason requires, the test for each individual citizen is to determine whether they can identify reasons which they can reasonably expect others to share, and this last is what the convergence view rejects.

This has been defended as more faith friendly than the Rawlsian model as it would allow citizens to vote on the basis of reasons drawn solely from their religious faith, converging, it is hoped, with others who have their own reasons, religious or otherwise for backing the measure in question (Gaus, 2009: 9). This view, it is claimed is more faithful to the fact of pluralism, in that it takes a more clear eyed view of the depth of our disagreements, and responds by allowing for a plurality of acceptable reasons in the political sphere. The Rawlsian account, by contrast, responds to the fact of pluralism by allowing an unacceptable degree of idealisation in responding to ostensible disagreement. The Rawlsian, committed to finding shared reasons, responds to actual disagreement, it is suggested, by refusing to recognise this as an obstacle, dismissing it in favour of a consideration of what one's interlocutor would, ideally, have reason to endorse if they had access to more perfect information etc. (Gaus, 2009). The public reason liberal, on this view, does not take seriously the depth of the religious citizen's attachment to their faith, and may be guilty of resorting to 'browbeating' those who do not appear to have the appropriate reasons, i.e. those the liberal believes they ought to share. ${ }^{1}$ The convergence model of public reason appears more inclusive than the Rawlsian model, as it relieves religious citizens of the obligation to find additional non-religious reasons in support of their favoured measures - religious reasons are sufficient. The duty of civility is effectively abandoned as we may converge on a public policy without having to find justifications which all of our fellow citizens may be reasonably be expected to endorse (Gaus, 2009: 13).

\footnotetext{
${ }^{1}$ This criticism is first articulated by Bernard Williams (1981), whose contrast between internal and external accounts of practical reason underlies Gaus' critique of justificatory liberalism.
} 
In response, it would perhaps be fair to say that Rawls's statement of the idea of public reason does not sufficiently emphasise the importance of thinking about the particular situations of others in deliberating about the sorts of reasons that they could have for endorsing a particular measure. Scanlon's formulation of contractualism, while intended as an account of morality per se, rather than of public reason in the political sense, places much greater emphasis on the need to grapple with the situations of others in reasoning about what reasons they have (Scanlon, 1998). Following Scanlon, it is clear that discharging the duty of civility presupposes a willingness to understand where others are coming from, i.e. the way in which particular ethical and religious traditions shape their reasoning, even if we think of this as the starting point for deliberation rather than its conclusion. By contrast, Rawls' account of explaining one's faith as a means of reassuring the public of one's bona fides makes this sort of engagement appear incidental to public reasoning, rather than as essential to its conduct.

That said, if we are engage in forms of mutual justification, rather than simply seeking agreement, then some degree of idealisation will be inescapable, for otherwise we have simply replaced the idea of justification with that of actual consent. To count as reasoning at all a measure of idealisation is essential: we need to interpret why others respond as they do, what unstated reasons they may have and what they are in principle committed to, whether they realise this or not. How much idealisation is acceptable? If we end up idealising away all deep ethical disagreements, assuming something like perfect information, flawless reasoning etc. then we have gone too far (Scanlon, 1998: 32). If we were to idealise away the existence of religious faith (as one might suspect militant secularists do), or idealise away the fact that others have different religious commitments, then once, again, we have gone too far. On the other hand, interpretive charity can require us to go beyond what others say about their reason. It would be wrong, for instance, to take advantage of 
someone who is not skilled at articulating their understanding of their interests, by refusing to consider what could be said in their favour, rather than what was in fact said. Consider Rawls' proviso regarding the provision of public reasons for measures initially supported solely by religious reasons. Even if those who articulated the religious argument fail to provide the necessary public reasons, we can plausibly interpret the duty of civility as requiring us to consider whether we can think of public reasons that could be offered in favour of the measure in question, even if the believers in question fail, or even refuse, to articulate these reasons.

The convergence solution fails as a response to the demand for recognition of religious citizens as co-deliberators. It understands the constraint of public reason primarily as a form of censorship, restricting the political expression of religious citizens, but if the underlying issue is a question of social recognition, then what is at issue here, is not simply a question of freedom of expression, but the more basic issue of how we respond to the claims of religious citizens, i.e. whether we are recognising them as partners in deliberation. The insistence that we seek shared reasons is essential to directing us outwards, to reckon with the various situations of our fellow citizens. Relaxing this condition, then, is a recipe for justificatory parochialism. The convergence model gets rid of the constraints of Rawlsian public reason, but in doing so, also cements the civic indifference which gives rise to the complaint that religious citizens are not recognised as equal partners in political deliberation, for citizens need not engage with the reasons of those situated in other religious and ethical traditions - the obligation to consider whether we can share reasons having been lifted. The convergence model supports a liberalism so minimal that it will be unable to supply the recognition which religious citizens rightly demand. The limited, localised forms of justification entailed by the convergence model do not rely on citizens recognising themselves as participating in public deliberation about how to use their common coercive force: it is, ironically, a more far-reaching form of privatisation than that required by Rawlsian public reason. 


\section{Conclusion}

I have argued that the duty of civility does not impose unreasonable burdens on religious citizens, and that it has a positive role to play in ensuring that religious citizens are recognised as equal participants in public life. That the constraints of public reason count against theocratic ambitions is clear, but it should also be clear that far from disqualifying religious citizens as co-deliberators, the idea of public reason respects them as reasoning participants in democratic politics. Rawls (1997: 803) suggests that, 'without citizens' allegiance to public reason and their honoring the duty of civility, divisions and hostilities between doctrines are bound in time to assert themselves, should they not already exist.' It is clear why the religious right, where they have a realistic prospect of winning elections, might welcome an untrammelled majoritarian style of politics free from the mild constraints of the duty of civility, and possibly also free from other more formal restraints on majoritarianism, but much less clear why religious minorities and other religious citizens would welcome this. The weakening of justificatory demands proposed by critics of public reason is unlikely to make for a fairer, more inclusive, democratic politics.

\section{Acknowledgements}

I would like to thank Matteo Bonotti, Jonathan Seglow, the anonymous reviewers for the journal, and the participants in the Religion in Public Life workshop, QUB and in the Friday Ethics Workshop, QUB for their helpful comments on earlier drafts of this paper.

ANDERSON, ES (1999) What is the point of equality? Ethics, 109: 287-337. 
AUDI, R (1997) Liberal Democracy and the Place of Religion in Politics. In: AUDI, R and WOLTERSTORFF, N (eds.) Religion in the Public Square. New York: Rowman and Littlefield.

AUGUSTINE (1984) City of God, Harmondsworth, Penguin.

BONOTTI, M (2014) Political liberalism, free speech and public reason. European Journal of Political Theory, 14: 180-208.

DARWALL, SL (1977) Two Kinds of Respect. Ethics, 88: 36-49.

DARWALL, SL (2006) The Second-Person Standpoint, Harvard University Press.

DWORKIN, R (1981) What is equality? Part 2: Equality of resources. Philosophy \& Public Affairs, 10: 283-345.

EBERLE, CJ (2002) Religious conviction in liberal politics, Cambridge University Press.

ELSTER, J (1997) The Market and the Forum: Three Varieties of Political Theory. In: BOHMAN, J and REHG, W (eds.) Deliberative Democracy. Cambridge MA: MIT Press.

FERRARA, A (2009) The separation of religion and politics in a post-secular society. Philosophy and Social Criticism, 35: 77-91.

GALEOTTI, A (2002) Toleration as Recognition, Oxford, Oxford University Press.

GAUS, G (2009) The place of religious belief in public reason liberalism. Multiculturalism and moral conflict: 19-37.

GUTMANN, A and THOMPSON, DF (1996) Democracy and Disagreement, Cambridge, Mass, Belknap Press.

HABERMAS, J (2006) Religion in the public sphere. European journal of philosophy, 14: 1-25.

HOLPUCH, A (2015) Defiant Kentucky clerk summoned to federal court over gay marriage refusal. The Guardian [Online]. Available: https://www.theguardian.com/usnews/2015/sep/01/kentucky-clerk-kim-davis-same-sex-marriage-supreme-court [Accessed 2 February 2016].

HONNETH, A (1992) Integrity and Disrespect: principles of a conception of morality based on the theory of recognition. Political Theory, 20: 187-201.

HONNETH, A (2004) Recognition and Justice: Outline of a Plural Theory of Justice. Acta Sociologica, 47: 351-364.

JONES, P (1994) Bearing the Consequences of Belief. Journal of Political Philosophy, 2: 24-43.

LABORDE, C (2008) Critical Republicanism, Oxford, Oxford University Press.

LARMORE, C (2003) Public Reason. In: FREEMAN, S (ed.) The Cambridge Companion to Rawls. Cambridge: Cambridge University Press.

MARGALIT, A (1996) The Decent Society, Cambrdige MA, Harvard University Press.

MCBRIDE, C (2013) Recognition, Cambridge, Polity Press.

MCCONNELL, MW (2000) Believers as equal citizens. In: ROSENBLUM, N (ed.) Obligations of Citizenship and Demands of Faith. Princeton NJ: Princeton University Press.

MCFALL, L (1987) Integrity. Ethics, 98: 5-20.

PINKARD, T (1994) Hegel's Phenomenology, Cambridge, Cambridge University Press.

QUINN, P (1997) Political liberalisms and their exclusion of the religious In: WEITHMAN, PJ (ed.) Religion and Contemporary Liberalism. Notre Dame: Notre Dame University Press.

RAWLS, J (1996) Political Liberalism, New York, Columbia University Press.

RAWLS, J (1997) The Idea of Public Reason Revisited. University of Chicago Law Review, 64: 765-807. ROSEN, M (2012) Dignity, Cambridge MA, Harvard University Press.

SCANLON, T (1998) What We Owe To Each Other, Cambridge, MA, Belknap Press of Harvard University Press.

STRAWSON, PF (1974) Freedom and Resentment, and other essays, Methuen.

TAYLOR, C (1994) The Politics of Recognition. In: GUTMANN, A (ed.) Multiculturalism. Princeton NJ: Princeton University Press.

TAYLOR, C (2007) A Secular Age, Cambridge Univ Press.

VALLIER, K (2011) Against Public Reason Liberalism's Accessibility Requirement. Journal of Moral Philosophy, 8: 366-389. 
WALDRON, J (2002) God, Locke, and Equality, Cambridge, Cambridge University Press.

WILLIAMS, B (1981) Internal and External Reasons. Moral Luck. Cambridge: CAmbridge University Press.

WILLIAMS, R (2012) Faith in the Public Square, London, Bloomsbury.

WOLFF, J (1998) Fairness, respect, and the egalitarian ethos. Philosophy \& Public Affairs, 27: 97-122.

WOLTERSTORFF, N (1997a) The Role of Religion in Decision and Discussion of Political Issues. In:

AUDI, R and WOLTERSTORFF, N (eds.) Religion in the Public Square. New York: Rowman and Littlefield.

WOLTERSTORFF, N (1997b) Why we should reject what liberalism tells us for about speaking and acting in public for religious reasons. In: WEITHMAN, PJ (ed.) Religion and Contemporary Liberalism. Notre Dame: Notre Dame University Press.

YOUNG, IM (1990) Justice and the Politics of Difference, Princeton, N.J, Princeton University Press. 